\title{
A PIACORIENTÁCIÓ KULTURÁLIS ÉS MAGATARTÁSI MEGKÖZELÍTÉSÉNEK EMPIRIKUS ÖSSZEHASONLÍTÓ ELEMZÉSE
}

\author{
Kovács Bence - Szakály Zoltán - Kontor Enikő - Polereczki Zsolt
}

\begin{abstract}
Absztrakt: A vállalkozások piacorientációjával kapcsolatos kutatások közel 30 éves múltra tekintenek vissza és még ma sem jelenthető ki, hogy általánosan elfogadottá vált volna egy „uralkodó” megközelítés. A témakörrel foglalkozó szakemberek és kutatók általában két perspektíva egyikével próbálják megközelíteni és definiálni a fogalmat, vizsgálatunkban e két nézet legelterjedtebb módszereit vetjük össze, a viselkedési alapú MARKOR és a kulturális alapú MKTOR nemzetközileg bemért skálákat. Az összehasonlító elemzés alapját egy országos, reprezentatív, 250 elemủ vállalati megkérdezés képezi. A vizsgálat során meghatároztuk a vállalkozások piacorientációját külön a MARKOR és külön az MKTOR skálák alapján, majd a kapott eredményeket összevetettük és értékeltük a szakirodalom alapján.

Abstract: The researches launched into the market orientation of enterprises have a 30-year-old history but a generally accepted, so called "dominant" approach did not appear during this time. The experts and researchers dealing with the topic usually try to approach and define the concept with one of the two perspectives. The most common methodologies of these two approaches - the internationally tested behaviour-based MARKOR and the culture-based MKTOR scales - are compared and contrasted in our research. The base of our comparative research is a nationwide representative corporate questionnaire with a sample size of 250 . In the research, the level of the market orientation of the enterprises was determined separately with MARKOR and MKTOR scales, then the results were compared and evaluated according to the literature.
\end{abstract}

Kulcsszavak: piacorientáció, MARKOR, MKTOR, megbízhatóság és érvényesség

Keywords: market orientation, MARKOR, MKTOR, reliability and validity

\section{Bevezetés}

A piacgazdaságokban általánosan uralkodó koordinációs mechanizmust a piac intézménye látja el, kulcsfontosságú, hogy a hozzá közvetlenül kapcsolódó entitással, a vállalattal hatékonyan kapcsolódjon össze. Az 1980-as évek második felétől jelent meg a törekvés, hogy ezt a kapcsolódást, pontosabban a vállalat piaci irányultságát/orientációját megértsük (Berács, 2002). Felmerül a kérdés: egy dinamikusan változó környezetben milyen irányelv vezérelje a vállalati müködést? Kohli és Jaworski (1990) már a 90-es évek elején kifejtette azt a véleményét, hogy az elméleti síkon megalapozott vezérelvek csak korlátozottan ültethetők át a gyakorlatba. A megfogalmazott dilemmára adható válaszok közül a szerzőpáros a marketingkoncepció megvalósítására és gyakorlati oldalának erösítésére helyezte a hangsúlyt. Kotler (2012) szerint ma már a vállalatok jelentős része egyre inkább a holisztikus marketingkoncepcióval összeegyeztethető módon tevékenykedik, azaz a hosszú távú profitszerzés mellett a vevői igények kielégítését helyezik a vállalati fókuszba. Ezek a vállalatok olyan programok, folyamatok és tevékenységek kidolgozására és tervezésére támaszkodnak, amelyek figyelmet fordítanak az egyes feladatok jelentőségére és azok kölcsönös függőségi kapcsolatára. 


\subsection{A piacorientáció modellezése}

A piacorientáció megértéséhez 1988-ig kell visszamennünk. A piacorientációt Shapiro (1988) a szervezeti döntéshozatal folyamata és módja alapján írta le. Véleménye szerint akkor beszélhetünk egy vállalat esetén piacorientált magatartásról, ha a döntések meghozatalához szükséges információk végighaladnak a vállalat valamennyi funkcionális területén, divízióján és egységén. Ezzel egyrészt kiszürődnek a szükségtelen információk, másrészről kiegészíthetik azokat a megfelelő döntés megszületése érdekében, továbbá a folyamat során javul a szervezeti egységek elkötelezettsége és hozzáállása a meghozott döntés iránt (Shapiro, 1988).

1990-ben két kutatópáros egymástól függetlenül célul tűzte ki, hogy a piacorientációt stabil elméleti alapokra helyezzék és kialakítsanak egy módszert, amivel mérhetővé válik a vállalkozások által adaptált piacorientáció mértéke. Kohli és Jaworski (1990) a vállalatok magatartásának, viselkedésmódjának oldaláról közelítette meg a piacorientációt. Cikkükben három erőforrás együttállásaként definiálják a koncepciót, melyeket az 1 . ábra szemléletet.

\section{1. ábra: Kohli és Jaworski piacorientációs modellje}

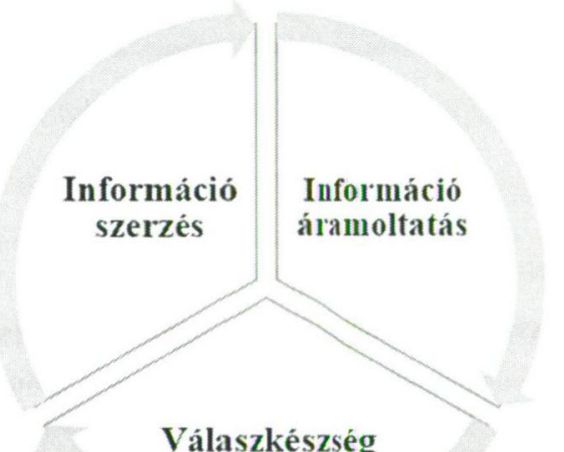

Forrás: Saját szerkeszés Kohli és Jaworski (1990) munkája alapján.

A szervezeteknek a döntéshozatalhoz szükséges információkat (1) gyüjteniük és allokálniuk kell a külső és belső környezetükről egyaránt, majd ezeket az információkat (2) a szervezet valamennyi szintjén terjeszteniük kell, hogy a funkciók együttmüködése javuljon, végül pedig (3) ki kell alakítaniuk egy válaszmechanizmust és meg kell hozniuk a céljaikkal és a környezettel leginkább összhangban lévő döntést/választ.

Narver és Slater (1990) megközelítése a kultúrára összpontosít. Vizsgálatuk során a piacorientáció mellett a tartós versenyelőny forrásaira is nagy hangsúlyt helyeztek. Szerintük a piacorientáció egy erős szervezeti kultúra, ami a tartós 
versenyelőnyök által determinált erőforrás konglomerátumaként határozható meg. A szervezeti kultúrát három oldalról vizsgálták:

(1) vevőrientáció: azaz a vállalat a döntései meghozatala során, milyen mértékben veszi figyelembe a vevők igényeit, hogyan viszonyul hozzájuk és mennyiben veti alá azknak a vállalati múködés irányvonalát.

(2) versenytárs-orientáció: egyrészt méri, hogy a piaci verseny milyen mélyen épült be a szervezeti kultúrába, másrészt a versenytársak nyomon követésének a tevékenysége.

(3) szervezeti egységek (funkciók) közötti együttműködés: azok a szervezeti egységek, melyek meghatározók a vállalati irányvonal kijelölésében, milyen mértékben kerülnek bevonásra a döntések meghozatalába és milyen a kommunikáció az egyes egységek között. A tartós versenyelőnyt pedig a hosszútávú szemlélet és a jövedelmezőség motívumával ragadták meg (Narver-Slater, 1990). Modelljüket a 2. ábra szemlélteti.

\section{2. ábra: Narver és Slater piacorientációs modellje}

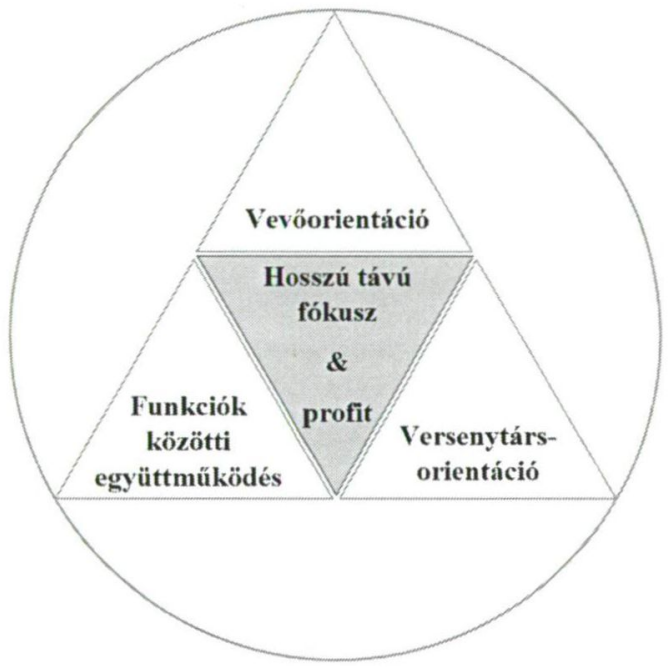

Forrás: Saját szerkesztés Narver és Slater (1990) munkája alapján.

Ha e két megközelítést közös nevezőre akarjuk hozni, akkor megfigyelhető, hogy a kulturális megközelítés is az információ megszerzésére (vevőorientáció és versenytárs-orientáció) és az információ terjesztésére (funkciók közötti együttmüködés) építkezik és a megfelelő válaszmechanizmus pedig a hosszú távú jövedelmezőségben jelenik meg (Kontor, 2014).

Ruekert (1992) stratégiai oldalról határozza meg a piacorientációt. A piacorientáció nem más, mint a vállalati célok elérése és az erőforrások hatékony allokálása érdekében kifejtett tevékenység, ami magában foglalja az információszerzést - nála elsősorban - a fogyasztókról.

Desphandé, Farley és Webster a piacorientációt szintén kulturális oldalról közelítették meg, azonban Narver és Slater modelljével ellentétben ők csak a 
vevőorientációt emelték ki mint meghatározó tényezőt. Ez utóbbit úgy definiálták mint a versenytárs-orientáció ellentétét. A piacorientáció szakirodalma ezt a megközelítést a vevői szemléletnek nevezte el (Desphandé et al., 1993).

Hunt és Morgan (1995) a komparatív versenyelmélettel foglalkozva kutatásaik során meghatározták a piacorientáció három kulcsterületét: (1) információszerzés a fogyasztókról és versenytársakról, (2) az információk szisztematikus elemzése azzal a céllal, hogy tudást szerezzünk a piacról, (3) az elemzés során levont következtetések beépítése a vállalati stratégia alkotási folyamatába. Munkásságuk talán leglényegesebb pontja, hogy a piacorientációra egy eszközökből és képességekből álló erőforrásként tekintettek.

A különböző koncepciókat áttekintve általánosságban kijelenthető, hogy bár számos megközelítés és definíció létezik a piacorientációra a szakirodalomban, a legmeghatározóbb a kulturális és a magatartás-alapú megközelítés. Mindkét perspektíva lényeges eleme az információ áramlása a szervezetben, valamint az információkra való válaszadási magatartás. (Becker-Homburg, 1999). Ha továbbmegyünk a szakirodalom feldolgozásában találkozhatunk Lafferty és Hult (2001) tipológiájával. A szerzőpáros öt megközelítést azonosított, mely szintén visszavezethető a fenti kettőre, ezek:

8. döntéshozó perspektíva

9. piaci intelligencia nézet

10. kulturális megközelítés

11. stratégiai megközelítés

12. fogyasztóorientált perspektíva.

Véleményünk szerint a fogyasztóorientált és a piaci intelligencia a kulturális nézethez esik közelebb, míg a stratégiai és a döntéshozó megközelítés sokkal inkább viselkedésalapú szemléletmód. Az eddig bemutatott modelleket az 1. táblázat foglalja össze.

\begin{tabular}{|c|c|c|c|c|}
\hline \multicolumn{5}{|c|}{ 1. táblázat: A piacorientációs modellek összefoglalása } \\
\hline \multicolumn{2}{|c|}{$\begin{array}{c}\text { Kulturális fókusszal } \\
\text { rendelkezö }\end{array}$} & \multicolumn{3}{|c|}{ Vezetői szemléletre koncentráló } \\
\hline $\begin{array}{l}\text { Desphande } \\
\text { et al. }\end{array}$ & $\begin{array}{l}\text { Narver, } \\
\text { Slater }\end{array}$ & Kohli, Jaworski & Shapiro & Ruekert \\
\hline $\begin{array}{l}\text { Vevö- } \\
\text { orientáció }\end{array}$ & $\begin{array}{l}\text { Vevö- } \\
\text { orientáció }\end{array}$ & $\begin{array}{l}\text { Információ- } \\
\text { gyüjtés }\end{array}$ & $\begin{array}{l}\text { Vállalati } \\
\text { funkciók } \\
\text { ellátása } \\
\text { információval }\end{array}$ & $\begin{array}{l}\text { Információ- } \\
\text { szerzés a } \\
\text { fogyasztókról }\end{array}$ \\
\hline & $\begin{array}{l}\text { Versenytárs- } \\
\text { orientáció }\end{array}$ & $\begin{array}{l}\text { Információ } \\
\text { áramoltatás }\end{array}$ & $\begin{array}{l}\text { Stratégia és } \\
\text { taktika alkotás }\end{array}$ & $\begin{array}{l}\text { Vevöorientált } \\
\text { stratégia } \\
\text { alkotása }\end{array}$ \\
\hline & $\begin{array}{l}\text { Funkciók } \\
\text { közötti } \\
\text { együttmü- } \\
\text { ködés }\end{array}$ & Válaszkészség & Döntések & $\begin{array}{l}\text { Stratégia } \\
\text { megvalósítása }\end{array}$ \\
\hline
\end{tabular}

Forrás: Moll et al. (2007). 


\subsection{A piacorientáció mérésére használt skálák}

Miután a piacorientáció elméleti bázisa meghatározásra került, fontossá vált, hogy valamilyen módon mérhetővé is váljon. A következőkben a legelterjedtebb három mérési módszer kerül ismertetésre: a MARKOR, az MKTOR és a DFW skála. Mindhárom mérési eszköz ún. Likert-skálákból áll. Az elméleti alaptól függően a szerzők meghațározták a skálák dimenzióit (például versenytárs-orientáció, vevőorientáció, funkciók közötti együttműködés), majd az egyes dimenziókba olyan változók kerültek, amik már mérhető tevékenységek. Ezek lettek a mérési modell indikátorai, míg a dimenziók a modell látens változói. Mindezek alapján a piacorientáció pedig egy olyan látens változó, amit a látens változók (a dimenziók) determinálnak Így a modellekre egy többszintű, hierarchikus összefüggésként lehet tekinteni: a mért változók/indikátorok meghatározzák a piacorientáció dimenzióit/látens változóit, amik együtt teremtik meg a piacorientációt, ami ez alapján az összefüggés alapján szintén egy látens változó. A modellek jellemvonása, hogy nem határoznak meg szinteket, ami alatt piacorienáltnak tekinthető vagy nem tekinthető piacorientáltnak egy vállalat. Sokkal inkább úgy fogható fel mindegyik skála, hogy a „0" piacorientációs szintről indul és így halad fölfelé a skálák végpontjáig. Például, ha a MARKOR skála esetén szummációval határoznánk meg a piacorientáció szintjét, akkor a skála indulóértéke (ha a válaszadó minden kérdésre válaszolt) $32(32 * 1)$ a végpontja pedig $160(32 * 5), 5$ fokozatú Likert-skálát alkalmazva.

A MARKOR skála Kohli és Jaworski magatartás alapú megközelítésén alapszik. Az eredetileg 20, majd késöbb 32 tényezöböl álló skála három dimenzió mentén határozza meg a piacorientációt: információszerzés, információ áramoltatás és válaszkészség, melyek fentebb részletesen kifejtésre kerültek (Kohli et al., 1993).

Az MKTOR skála Narver és Slater kulturális alapú perspektívájára épül. Ám mivel a kulturális tényezőket nehéz objektíven mérni, így a skála három dimenziója (versenytárs-orientáció, vevőorientáció és funkciók közötti együttmüködés) eredetileg 15 , később 17 viselkedésalapú változóval/indikátorral határozza meg a piacorientáció mértékét (Narver-Slater, 1990; Brettel el al., 2007).

Desphandé, Farley és Webster (1993) létrehozott egy kilenc állításból álló skálát (DFW), ami a fogyasztóorientáció, a vállalati kultúra és a szervezeti innováció mérésével határozza meg a piacorientáció szintjét. Később Desphandé felülvizsgálva korábbi eredményeit és szintetizálva a három skálát létrehozott egy hibrid eszközt (MORTN), ami még mindig elsősorban a fogyasztóorientációra helyezte a hangsúlyt és 10 állításból épül fel (Desphand-Farley, 2004).

\subsection{A skálák összehasonlító vizsgálatai}

Desphandé és Farley (1998) egy empirikus kutatás során, ahol mindhárom skála alkalmazásra került (MARKOR, MKTOR, DFW) arra a megállapításra jutottak, hogy a három skála bár elméleti alapját tekintve jelentősen eltér egymástól, mégis nagyjából ugyanazt az eredményt adja. A skálák kapcsolatát vizsgálva 0,6 körüli Person-féle korrelációs együtthatót kaptak. 
Gauzante (1999) a MARKOR és MKTOR skála szókincsgazdagságát és érthetőségét szemantikai tartalomelemzéssel vizsgálta, bár az általa vizsgált skálák még a frissítésük elöttiek (azaz 20 és 14 eleműek). Arra a következtetésre jutott, hogy ugyan mindkét skála megfelel az alkotóik piacorientáció-meghatározásának, ám a MARKOR skála szóhasználata változatosabb, ugyanakkor a számos igeidő használatával több esetben is félreéthetôvé válnak az állítások. Felhívja rá a figyelmet, hogy a statisztikai vizsgálatok mellett a szemantikai szerkezetet is célszerü figyelembe venni, mert megtévesztő eredményeket adhat egy-egy kétértelmü meghatározás.

González-Benito és González-Benito (2005) cikke szerint a piacorientációs kutatások kb. 40\%-a a MARKOR és 35\%-a az MKTOR skálát alkalmazza és mindössze 5\%-a veszi figyelembe egyszerre mindkét elméletet. Arra a következtetésre jutottak, hogy bár más a skálák alapja, mégis azok nem egymást kizáróan képesek mérni a piacorientáció szintjét, ugyanis a két skála eltérő aspektusból, de ugyanazt a jelenséget méri megfelelő hatásfokkal és hasonló eredménnyel.

Oczkowski és Farrell (1997) a MARKOR és az MKTOR skálát egyaránt elemezték megbízhatósági és érvényességi vizsgálatokkal. Eredményei szerint bár a Cronbach alfa alapján mindkét skála dimenziói megbízhatónak tekinthetők, a CFA elemzés ezt nem igazolja és a skálák jelentős adaptálására van szükség. Az eredeti és az adaptált modellek esetében is az MKTOR teljesített jobban összehasonlító vizsgálatuk során.

\section{Célkitüzés, anyag és módszer}

A kutatás célkitüzése, hogy a vizsgált körben (hazai élelmiszeripari és mezőgazdasági kis- és közepes vállalatok) összehasonlítsuk a MARKOR és az MKTOR skálát, tesztelve azok megbízhatóságát (reliabilitását) és érvényességét (validitását).

A kutatásunk alapját egy kérdőíves megkérdezés képezi, mely során 250 hazai élelmiszeripari és mezőgazdasági kis- és közepes vállalkozást kérdeztek meg. A kérdőivet a Kaposvári Egyetem Marketing és Kereskedelem Tanszékének alkalmazottai állították össze és a lekérdezést a pécsi székhelyü Szocio-Gráf Piackutató Kft. bonyolította le 2010-ben. A minta reprezentatív a KSH 2009 negyedik negyedévi CÉG-KÓD-TÁR kiadványában szereplö 10 (kivéve 109) és 11 , valamint 01 és 03 TEÁOR szám és vállalati méretkategória alapján, a mintavétel véletlenségét pedig egy véletlenszámgenerátor biztosította. Az adatbázisból több cikk és tanulmány készült, ám a vizsgálat tárgyát képezö kutatási kérdésben még nem került felhasználásra korábban az adatbázis.

A kutatás módszertana három fö blokkra bomlik: megbízhatóság (reliabilitás) vizsgálata, az érvényesség (validitás) vizsgálata és a skálák eredményeinek összehasonlítása.

A skálák megbízhatósági vizsgálata során első lépésként a Cronbach alfa mutatót határoztuk meg, ez a mutató a legszélesebb körben elterjedt eszköz a skálák megbízhatóságának mérésére (Peterson-Kim, 2013). Az alfa az egyszerü 
tesztfelezés helyett az összes lehetséges tesztfelezés korrelációs együtthatójának számtani átlaga, értéke 0,7 fölött rendszerint megbízhatóságot jelent és elfogadható megbízhatóságú modellt feltételez, 0,9 fölötti értékét pedig egyenesen kiválónak tekintik. Hátrányaként szokták emlegetni, hogy a változók számának növekedésével nő az alfa értéke is, azaz, ha sok a változónk az adott skálában, akkor megtévesztő eredmény születhet (Malhotra-Simon, 2008; Hair et al., 2010). Épp emiatt javasolt más mutatók alkalmazása is. A szakirodalom alapján a composite reliability (CR) és az átlagos magyarázott variancia (Average Variance Extracted - AVE) mutatókat választottuk (Malhotra-Simon, 2008; Hair et al., 2010).

A CR mutató, mivel egy többváltozós adatredukciós módszerre (fökomponens,fötengely-, vagy faktorelemzés) épít, figyelembe veszi, hogy az egyes indikátorváltozók eltérő súllyal járulnak hozzá a látens változó meghatározásához, jelen esetben ezek a látens változóink az információszerzés, információáramoltatás, válaszkészség, vevőorientáció, versenytárs-orientáció, funkciók közötti együttmüködés. Egészen pontosan a CR mutató a faktorsúlyok standardizált értékét és a becslés relatív hibáját használja fel a következő képlet alapján:

$$
C R=\frac{\left(\sum_{i=1}^{n} \lambda_{i}\right)^{2}}{\left(\sum_{i=1}^{n} \lambda_{i}\right)^{2}+\sum_{i=1}^{n} \varepsilon_{i}},
$$

ahol:

$\mathrm{n}=$ itemek/ változók száma

$\lambda=$ faktor/fökomponens standardizált súlyok

$\varepsilon=$ a becslés hibája, azaz $1-\lambda^{2}$

A CR mutató Raykov (1997) alapján került kiszámításra manuálisan. Az EVA mutató, azaz az átlagos magyarázott variancia egyszerüen a magyarázott variancia összege (ez a $\lambda^{2}$ összege) osztva az itemek számával. A CR mutató értékét az alfához hasonlóan 0,7 fölött tartjuk megfelelőnek (Hair et al., 2010), bár egyes források a 0,6 fölötti értéket is elfogadják (Malhotra-Simon, 2008). Az EVA esetén a küszöbérték 0,5, ez azt jelenti, hogy átlagosan magyarázzuk a faktor-/fökomponens/fötengelyelemzés esetén a variancia $50 \%$-át. Véleményünk szerint egy megbízható modell esetén még ez is kevés, mert a 0,5 azt jelenti, hogy az $50 \%$-át nem tudjuk magyarázni, tehát a variancia felét nem képes megragadni a modell.

A kutatás következő lépésében az érvényességi vizsgálatok közül a CFA (konfirmatorikus faktor elemzés) került előtérbe, ám magát az eljárást nem részletezzük jelen tanulmányban, csupán az eredeti modellek érvényességét tükröző mutatókat mutatjuk be, melyeket a CFA elemzés biztosít számunkra, ezek: $\chi^{2}$ próba; CFI; GFI; AGFI; RMSEA; NFI; NNFI (TLI); SRMR; RMR.

A $\chi^{2}$ próba teszteli a feltételezett modell illeszkedését az adatokra azáltal, hogy összeveti a feltételezett és megfigyelt kovariancia mátrixokat. A CFI (comparative fit index) összehasonlító illeszkedési index a $\chi^{2}$ próba elemszám érzékenységét korrigálja, értéke általában 0,9 fölött jó. A GFI (goodness of fit index) és AGFI (adjusted goodness of fit) a feltételezett és a tényleges kovariancia mátrix egybevágóságát méri a kettő közötti különbség meghatározásával, az utóbbi mutató 
kevésbé érzékeny az elemszámra, értékük egyaránt 0,9 fölött elfogadható. Az RMSEA (Root mean square error of approxiamtion) a megközelítési négyzetes középérték hiba szintén ugyanazt méri mint az előző, azzal a különbséggel, hogy egyáltalán nem érzékeny az elemszámra, úgy értelmezhetö, hogy a 0,07 alatti értékek tekinthetők elfogadhatónak. Az NFI és NNFI (normed és non-normed fit index) utóbbit nevezik TLI-nek (Tucker-Lewis indexnek) is - a modellilleszkedést méri a $\chi^{2}$ próbára építve. A kettö közt a különbség, hogy az utóbbi kevésbé érzékeny az elemszámra, ám néha téves eredményt adhat. Értéke 0 és 1 között változhat és a 0,95 fölötti értéket tekinti a szakirodalom érvényes modellnek az illeszkedés alapján. Az RMR és SRMR (root mean square residual és square root mean square residual), azaz a négyzetes reziduális átlag, illetve a standardizált négyzetes reziduális átlag a tényleges és a feltételezett modell kovariancia mátrixainak különbségének a négyzetgyöke, mindkettő értéke akkor tekinthető jónak, ha 0,08 alatti vagy az SRMR esetén minél alacsonyabb (Hooper et al., 2008).

A modellek érvényességének van még egy feltétele, a látens változókat a saját indikátorai nagyobb mértékben kell, hogy magyarázzák, mint bármely más látens változó (különbözöségi érvényesség discriminant validity). Ez a gyakorlatban azt jelenti, hogy az AVE mutatónak nagyobbnak kell lennie, mint a modellben szereplö bármely másik látens változóval való determinációs együtthatója $\left(R^{2}\right)$. A különbözőségi érvényesség legegyszerübben így írható fel Henseler et al. (2015) alapján saját átirat formájában:

ahol:

$$
A V E \geq \max \left(\frac{\sum_{i=1}^{n}\left(x_{i}-\bar{x}\right)\left(y_{i}-\bar{y}\right)}{(n-1) s_{x} s_{y}}\right)^{2},
$$

$\mathrm{n}=$ elemszám

AVE=átlagos magyarázott variancia

$x_{i} ; y_{i}=\mathrm{x}$ és y i-edik eleme

$\bar{x} ; \bar{y}=\mathrm{x}$ és y számtani közepe

$s_{x} ; s_{y}=\mathrm{x}$ és y tapasztalati korrigált szórása

Az elemzést az $\mathrm{R}$ Statistics 3.4.2-es verziójával végeztük az $\mathrm{R}$ Studio szerkesztőben, a vizsgálatok során az alábbi bővítmények kerültek alkalmazásra: psych és lavaan. Ez alól kivételt képez az AVE és CR mutató, melyek hagyományosan, manuális úton kerültek kiszámításra megbízható programcsomag hiányában.

\section{Eredmények és értékelésük}

\subsection{A megbízhatóság (reliabilitás) vizsgálata}

A Cronbach alfa mutató szoftverrel történő meghatározása azért is előnyös számunkra, mert a vizsgált indikátorok reliabilitása mellett meghatározza az alfa értékét minden egyes olyan esetben, ha egy-egy adott változót eltávolítunk a skálából. A 2. táblázatban látható a számított alfa, CR és EVA értéke, illetve, hogy 
a skála reliabilitása az alfa szerint javítható-e egy-egy változó eldobásával. Az első oszlopban a látens változók láthatók, a felső három (információszerzés, információáramoltatás, válaszkészség) a MARKOR, míg az alsó három az MKTOR skála dimenziója. Ha alaposan megnézzuik a táblázatot, láthatjuk, hogy a Cronbachféle alfa alapján valamennyi dimenzió az elfogadható tartományba került és megbízható skálát tükröz, ezek az eredmények megegyeznek Kovács et al. (2016) eredményeivel, mely egy másik, bár nem reprezentatív mintán végzett vizsgálat. Továbbá azt is látjuk, hogy nem tudjuk javítani a megbízhatóságot változók törlésével, a problémát csak akkor észleljük, ha megnézzük a CR és AVE mutatókat, ahol már közel sem nevezhető „,rózsásnak” a helyzet. Emlékeztetőül a CR értékének 0,7 fölött az AVE értékének pedig 0,5 fölött kell lennie. A MARKOR skálánál nagyon rossz a kép, kiváltképp az információszerzés és a válaszkészség dimenzióknál, a composit reliability értéke még a 0,6-ot sem éri el. Az átlagos magyarázott variancia pedig $50 \%$ alatt van mindegyik esetben, ami annyit jelent, hogy a modell nem magyarázza a piacorientáció szóródásának több, mint a felét. Ehhez képest az MKTOR skála már sokkal jobb eredményt mutat, bár a CR értéke egy esetben (vevőorientáció) itt sem éri el a Hair et al. (2010) szerinti küszöbértéket (ugyanakkor Malhotra és Simon (2008) kritikus értékét, ami 0,6, meghaladja). Az AVE mutató viszont minden esetben eléri a szükséges határt. Mindezek az eredmények föként azért tünnek feltünően furcsának, mivel az alfa teljesen más eredményt tükröz (jelen esetben jó megbízhatóságú modellt), ebből is legfőképp az látható, hogy nem elég a már megszokott mutatók alkalmazása, mert a probléma gyakran mélyebben gyökerezik, mint ami az összes felezési korrelációs együttható átlagával meghatározható lenne. Ezt összefoglalva a MARKOR modell a reliabilitási vizsgálatok alapján nem megfelelő, míg az MKTOR modell megbízhatósága elfogadható.

\section{2. táblázat: Megbízhatósági vizsgálatok $(\mathrm{N}=199)$}

\section{Cronbach alfa}

\begin{tabular}{lcccc} 
& \multicolumn{2}{c}{ Cronbach alfa } & CR & AVE \\
& Errték & Javítható? & & \\
Információszerzés & 0,84 & nem & 0,874 & 0,412 \\
Információáramoltatás & 0,82 & nem & 0,551 & 0,456 \\
Válaszkészség & 0,91 & nem & 0,541 & 0,317 \\
Vevőorientáció & 0,87 & nem & 0,655 & 0,594 \\
Versenytárs-orientáció & 0,82 & nem & 0,761 & 0,734 \\
Funkciók közötti együttmüködés & 0,86 & nem & 0,905 & 0,705
\end{tabular}

Forrás: Raykov (1997) és Hair et al. (2010) alapján saját számítások.

\subsection{Az érvényesség (validitás) vizsgálata}

Továbblépve a validációs vizsgálatokra konfirmatorikus faktor elemzéssel vizsgáltuk a modelleket. Ezek alapján pedig azt állapíthatjuk meg, hogy nem valid egyik modell sem a vizsgálat tárgyát képező körben (magyarországi élelmiszeripari és mezögazdasági kis- és közepes vállalkozások). A táblázatban látható az egyes mutatók küszöbértéke, valamint, hogy egyik modell sem felel meg az elvárt 
kritériumoknak. A $\chi^{2}$ próba alapján a feltételezett modellek (MARKOR és MKTOR) nem illeszkednek az empirikus eredményekre, ezt alátámasztják a táblázatban található további mutatók is. Azonban azt azért észre kell venni, hogy mindegyik esetben az MKTOR skála jobban teljesít. Bár ez sem közelíti meg a küszöbértékeket, mégis jobb eredmények adódnak az egyes mutatókat tekintve, ami pedig nem tudható be annak a ténynek, hogy a változószám alacsonyabb az MKTOR skálánál, mivel a kevésbé érzékeny mutatók esetén is eltérést látunk a két modell között az utóbbi javára. Ezek az eredmények összecsengenek Oczkowski és Farrel (1997) kutatásának eredményével. A szerzőpáros hasonló értékeket ért el a mutatókat tekintve, mind a MARKOR, mind az MKTOR skála esetén az eredeti modellt tesztelve, továbbá ők is arra jutottak, hogy az eredeti, módosítatlan modelleket tekintve az MKTOR skála közelebb áll az érvényességhez, mint a MARKOR (bár nem valid egyik sem).

\begin{tabular}{lccc}
\multicolumn{3}{c}{ 3. táblázat: Az érvényességi vizsgálat eredménye $(\mathbf{N}=\mathbf{2 1 6})$} \\
Mutató & Kritérium & $\begin{array}{c}\text { MARKOR } \\
\text { MKTOR }\end{array}$ \\
$\chi^{2}$ (szf.) & & $1570,311(461)$ & $603,349(116)$ \\
$\chi^{2}$ stat. $p$-értéke & $\geq 0,05$ & 0,000 & 0,000 \\
CFI & $\geq 0,95$ & 0,690 & 0,779 \\
GFI & $\geq 0,95$ & 0,643 & 0,713 \\
AGFI & $\geq 0,95$ & 0,591 & 0,621 \\
RMSEA & $\leq 0,07$ & 0,107 & 0,139 \\
NFI & $\geq 0,95$ & 0,612 & 0,742 \\
NNFI (TLI) & $\geq 0,95$ & 0,667 & 0,741 \\
SRMR & $\leq 0,08$ & 0,110 & 0,088 \\
RMR & alacsony & 0,126 & 0,09
\end{tabular}

Forrás: Hooper et al. (2008) alapján saját számítások.

Természetesen a vizsgálat tovább folytatható lenne a változók számának csökkentésével a modifikációs indexek, a standardizált együtthatók és a kovariancia mátrixok standardizált eltérései alapján annak érdekében, hogy a 3. táblázat mutatóit az elfogadható kategóriába ,tornázzuk”.

$\mathrm{Az}$ érvényes modell másik feltétele a különbözőség, azaz, hogy a látens változóinkat az indikátorai nagyobb mértékben magyarázzák, mint a modellben szereplő másik két látens indikátorai. Ehhez össze kell vetnünk az egyes látens változók AVE értékét az adott látens változó és a modellben szereplő másik két látens változó korrelációs együtthatójának négyzetével. Akkor beszélhetünk különbözöségi érvényességröl, ha az AVE mutató értéke meghaladja a determinációs koefficiens $\left(\mathrm{R}^{2}\right)$ értékét. Az összevetésből kiderült, hogy a MARKOR esetében nem beszélhetünk különbözőségi érvényességről (discriminant validity) a látens változókat tekintve, mivel az információszerzés esetén az $A V E_{A}$ értéke $0,412<R_{A}^{2}$, $\mathrm{B}=0,53$. Az információáramlásnál az $A V E_{B}=0,456<R_{A}^{2}, B=0,53$, szintén ezt láthatjuk a válaszkészségnél: $A V E_{C}=0,317<R^{2}{ }_{B}, C=0,49$. $A z$ MKTOR modell ellenben már teljesíti ezt a feltételt. Vevőorientáció: $A V E_{D}=0,594>R^{2}, F=0,42$; versenytárs- 
orientáció: $A V E_{E}=0,734>R_{E}^{2}, F=0,42$; funkciók közötti együttmüködés: $\mathrm{AVE}_{\mathrm{F}}=0,705>\mathrm{R}_{\mathrm{D}}^{2} \mathrm{~F}=0,42$.

\subsection{A MARKOR és MKTOR modell eredményeinek összehasonlítása}

A fenti eredmények alapján nem kíséreltünk meg végrehajtani egy igazi többváltozós adatredukciós eljárást (fökomponens-/fötengely-/faktorelemzés). Ezért az egyes dimenziókat úgy csökkentettük egy-egy változóra, hogy a skála értékeit szummáztuk külön a MARKOR és az MKTOR skála 3-3 tényezőjénél a pszichológiában (pl. személyiségteszteknél) gyakran alkalmazott módon (Rózsa et al., 2006). Majd a piacorientáció szintjét e szummázott skálák alapján határoztuk meg külön-külön a két modell alapján fökomponens elemzés segítségével (itt már azért tudtuk alkalmazni a fökomponens eljárást, mert a szummáció hatására csökken az egyes válaszokban rejlö relatív hibák súlya a vizsgálat során). A Kaiser-Meyer-Olkin kritérium MSA értéke a MARKOR skála esetében 0,68, míg az MKTOR esetében 0,73, azaz a fökomponens elemzés még éppen használható. Természetesen a szummázott skálákat az adatredukció előtt standardizáltuk. A MARKOR modellnél a kapott komponensben az egyes dimenziók az alábbi módon jelennek meg (főkomponens súlyok): információszerzés: 0,88 ; információáramlás: 0,91 ; válaszkészség: 0,80. Az MKTOR modell fökomponens elemzése alapján a főkomponens súlyok: vevőorientáció: 0,87 ; versenytárs-orientáció: 0,87 ; funkciók közötti együttmüködés: 0,88 . A skálák, valamint a skálák dimenzióinak kapcsolatát Spearman-féle rangkorrelációval vizsgáltuk. Az eredmények a 4. táblázatban láthatók.

\begin{tabular}{ccccccccc}
\multicolumn{8}{c}{ 4. táblázat: A piacorientáció és dimenzióinak kapcsolata $(N \in[214 ; 237])$} \\
Infsz. & Infa. & Valk. & Vero. & Vto. & Fke. & markor & mktor \\
Infsz. & $1,00^{*}$ & $0,71^{*}$ & $0,40^{*}$ & $0,37^{*}$ & $0,50^{*}$ & $0,45^{*}$ & $0,87^{*}$ & $0,51^{*}$ \\
Infa. & $0,71^{*}$ & $1,00^{*}$ & $0,49^{*}$ & $0,47^{*}$ & $0,60^{*}$ & $0,49^{*}$ & $0,90^{*}$ & $0,62^{*}$ \\
Valk. & $0,40^{*}$ & $0,49^{*}$ & $1,00^{*}$ & $0,71^{*}$ & $0,62^{*}$ & $0,65^{*}$ & $0,69^{*}$ & $0,75^{*}$ \\
Vero. & $0,37^{*}$ & $0,47^{*}$ & $0,71^{*}$ & $1,00^{*}$ & $0,54^{*}$ & $0,58^{*}$ & $0,58^{*}$ & $0,84^{*}$ \\
Vto. & $0,50^{*}$ & $0,60^{*}$ & $0,62^{*}$ & $0,54^{*}$ & $1,00^{*}$ & $0,58^{*}$ & $0,67^{*}$ & $0,81^{*}$ \\
Fke. & $0,45^{*}$ & $0,49^{*}$ & $0,65^{*}$ & $0,58^{*}$ & $0,58^{*}$ & $1,00^{*}$ & $0,59^{*}$ & $0,85^{*}$ \\
markor & $0,87^{*}$ & $0,90^{*}$ & $0,69^{*}$ & $0,58^{*}$ & $0,67^{*}$ & $0,59^{*}$ & $1,00^{*}$ & $0,72^{*}$ \\
mktor & $0,51 *$ & $0,62^{*}$ & $0,75^{*}$ & $0,84^{*}$ & $0,81^{*}$ & $0,85^{*}$ & $0,72^{*}$ & $1,00^{*}$
\end{tabular}

*p-érték $<0,01$

Forrás: Saját számítások alapján.

Infsz.: információszerzés; Infa.: információáramoltatás; Valk.: válaszkészség; Vero.: vevőorientáció; Vto.: versenytárs-orientáció; Fke.: funkciók közötti együttmüködés; markor: MARKOR szerint mért piacorientáció; mktor: MKTOR szerint mért piacorientáció

A táblázatban látható, hogy valamennyi korrelációs koefficiens szignifikáns 95\%-os megbízhatósági szint mellett az $F$-próba alapján. Értelemszerüen a MARKOR skála a hozzá tartozó dimenziókkal mutat erős szignifikáns kapcsolatot, míg az MKTOR a saját látens változóival (ez jelzi az adatredukció hatásosságát is). Itt kell kiemelnünk, hogy a MARKOR és az MKTOR skála rangkorrelációs együtthatója 0,72 , azaz erős korrelációs kapcsolat tapasztalható a két skála között, 
ami még a Desphandé és Farley (1998) vizsgálatánál tapasztalható kapcsolatnál is erősebb. Bár az MKTOR skáláról megbízhatósági vizsgálatok alapján kijelenthetjük, hogy valószínüleg a mérése megbízható (bár a validitásáról ugyanez nem mondható el) ugyanakkor ezt a MARKOR skáláról nem tudjuk megtenni, mégis a korrelációs kapcsolat azt mutatja, hogy nagyrészt ugyanazt a ,jelenséget” méri a két modell. Ebböl feltételezhető az, hogy hasonlóbb eredményre (erősebb kapcsolatra) hozható a kettő, ha elvégezzük a CFA elemzés validálási folyamatát, s így remélhetőleg azok a változók esnek ki, amik a kettő közötti eltérésért felelösek. Mindez persze csak akkor igaz, ha elfogadjuk, hogy a két megközelítés (kulturális és magatartási) ekvivalens egymással, csupán más módon közelíti meg ugyanazt a jelenséget, a piacorientációt.

A skálák dimenzióinak összehasonlításából elsősorban az inter-scale, azaz a skálák közötti összehasonlítás az érdekes. Vegyük észre, hogy a válaszkészség erősebb kapcsolatban van a másik skála tényezőivel, mint a vele egy skálába tartozókkal (ami nem gond, sőt elvileg így logikus, hisz skálán belül (intra-scale) a dimenziók más és más „dolgot” mérnek). Külön kiemelhető a válaszkészség és a vevőorientáció kapcsolata $(\rho=0,71)$. Ez feltehetően azért van, mert a válaszkészség dimenzióban túlnyomó részt, olyan indikátorok jelennek meg, amik a marketingkoncepciónak megfelelően a fogyasztó igényeinek rendelik alá a szervezet müködését (Kotler-Keller, 2012). Továbbá a válaszkészség és a funkciók közötti együttmüködés erős kapcsolata is $(\rho=0,65)$ logikailag helytállónak tünik véleményünk szerint, mivel a megfelelö válaszmechanizmus megköveteli a szervezet funkcionális területinek összehangolt müködését. Akkor képes a szervezet a megfelelő döntés meghozatalára, ha a döntésbe a (megfelelö) szintek kapcsolódnak be azáltal, hogy a megfelelő információkat szolgáltatják a döntés meghozatalához, amihez elengedhetetlen a funkciók együttmüködése. Ez magyarázat lehet közvetve a válaszkészség és a versenytárs-orientáció kapcsolatára is $(\rho=0,62)$, mivel a döntési folyamat első szakasza, azaz a probléma felmerülése és észlelése nemcsak a vevöi oldalról, illetve a szervezeten belülről érkezhet, hanem a piaci verseny is indukálhatja a problémát.

\section{Következtetések, összegzés, záró megjegyzések, záró gondolatok}

Az első és legfontosabb következtetése a kutatásnak, hogy véleményünk szerint nem elegendő a megszokott, jól bevált módszerrel tesztelnünk a skálák reliabilitását. Rendelkezésünkre állnak olyan eszközök is (CR, AVE), amik jóval több információt mutatnak meg számunkra a skálák konzisztenciájáról.

A második következtetés, hogy bár feltehetően (a korrelációs vizsgálatok alapján) a MARKOR és az MKTOR skála is ugyanazt méri (piacorientáció), mégis a vizsgálatban tapasztaltak alapján az MKTOR skála jelenleg alkalmasabbnak tünik a piacorientáció mérésére, bár fenntartásokkal.

A harmadik következtetés ezekhez a fenntartásokhoz kapcsolódik: egyik modell sem tesz eleget a validitás követelményének. Ennek több oka is lehet, melyek közül az egyik, hogy a skálák mára „kiöregedhettek” a megváltozott piaci tendenciák, trendek miatt. Másrészt feltehető, hogy más-más iparágakban/ágazatokban másként 
kell megközelíteni a piacorientációt és az uniformizált modellek erre nem biztos, hogy alkalmasak.

Mindezek alapján az a javaslatunk, hogy ezen standard skálákra (MKTOR, MARKOR) épülö piacorientációs kutatások esetén, a tényleges feltáró vizsgálatokat mindenképpen előzzék meg a megbízhatósági és validitási tesztek. Fentiekben ismertetett kutatásunkban az MKTOR modell bizonyította reliabilitását és feltehetően konfirmatorikus faktorelemzés segítségével elérhető a modell validitása is.

Jelen tanulmányunk egy hosszabb kutatási folyamat első fázisa, melyben a jelenleg legelterjedtebb piacorientációt mérő skálákat vetettük össze és teszteltük megbízhatóságukat, illetve érvényességüket. A kutatás következő lépéseként ezeknek a modelleknek a továbbfejlesztését tüztük ki célul.

\section{Köszönetnyilvánítás}

A publikáció megjelenését a GINOP-2.3.2-15-2016-00062 azonosítójú, " Életminőség fejlesztése Kelet-Magyarországon: Táplálkozás-, teljesítménybiológiai és biotechnológiai experimentális kutatások és eszközfejlesztések a humán megbetegedések megelőzésére és kezelésére" című projekt támogatta.

\section{Irodalomjegyzék}

Becker, J., Homburg, C. (1999): Market-Oriented Management: A System-Based Perspective. Journal of Market Focused Management, 4 (1): 17-41.

Berács J. (2002): Piacorientáció: Közgazdasági és marketing megközelítés. MTA Doktori értekezés, BKÁE, Budapest.

Brettel, M., Engelen, A., Heinemann, F., Kessell, A. (2007): The Role of Market-Oriented Organizational Culture in New Entrepreneurial Ventures. Journal of Research in Marketing and Entrepreneurship, 9 (1): 40-66.

Desphandé, R., Farley, J. U. (1998): Generalization and synthesis, Journal of Market-Focused Management, 2 (3): 212-232.

Desphandé, R., Farley, J. U. (2004): Organizational culture, market orientation, innovativeness, and firm performance: an international research odyssey. International Journal of Research in Marketing, 21 (1): 3-22.

Desphandé, R., Farley, J. U., Webster, F. E., Jr. (1993): Corporate Culture, Customer Orientation and Innovativeness in Japanese Firms: A Quadrad Analysis. Journal of Marketing, 57 (1): 23-37.

Gauzante, C. (1999): Comparing Market Orientation Scales: A Content Analysis. Marketing Bulletin, 10 (1): 76-82.

González-Benito, Ó., González-Benito, J. (2005): Cultural vs Operational Market Orientation and Objectives vs Subjective Performance: Perspective of Pro-duction and Operations. Industrial Marketing Management, 34 (8): 797-829.

Hair, J., Black, W., Babin, B., Anderson, R. (2010): Multivariate data analysis. Prentice-Hall, Inc. Upper Saddle River, NJ. USA.

Henseler, J., Ringle, C. M, Sarstedt, M. (2015): A new criterion for assessing discriminant validity in variance-based structural equation modeling. Journal of the Academy of Marketing Science, 43 (1): 115-135.

Hooper, D., Coughlan, J., Mullen, M. (2008): Structural Equation Modelling: Guidelines for Determining Model Fit. Electronic Journal of Business Research Methods, 6 (1): 53-60.

Hunt, S. D., Morgan, R. M. (1995): The Comparative Adventage Theory of Competition. Journal of Marketing, 59 (2): 1-15. 
Kohli, A. K., Jaworski, B. J. (1990): Market Orientation: The Construct, Research Proposition and Managerial Implications. Journal of Marketing, 54 (2): 1-18.

Kohli, A. K., Jaworski, B. J., Kumar A. (1993): MARKOR: A measure of market orientation. Journal of Marketing Research, 30 (4): 467-477.

Kontor E. (2014): Az eröforrás alapú elmélet és a marketing kapcsolódási pontjai - a piacorientáció mint marketing-erőforrás. Vezetéstudomány, 45 (12): 38-52.

Kotler, P., Keller, K. L. (2006): Marketing menedzsment. Akadémiai Kiadó, Budapest.

Kovács B., Szakály Z., Polereczki Zs. (2016): Az élelmiszeripari vállalkozások versenyelőnyeinek vizsgálata a piacorientáció tükrében. In: EMOK XXII. Országos Konferencia, Hitelesség és Értékorientáció a Marketingben Tanulmány Kötet, Debrecen, 608-618.

Lafferty, B. A., Hult, G. T. M. (2001): A synthesis of contemporary market orientation perspectives. European Journal of Marketing, 35 (1-2): 92-109.

Malhotra, N. K., Simon, J. (2008): Marketingkutatás. Budapest, Akadémiai Kiadó.

Moll, I., Montana, J., Fuzmán, F., Parellada, F. S. (2007): Market orientation and design orientation: a management model. Journal of Marketing Management, 23 (9-10): 861-876.

Narver, J., Slater, S. (1990): The effect of marketing orientation on business profitability. Journal of Marketing, 54 (4): 20-35.

Peterson, R. A., Kim, Y. (2013): On the relationship between coefficient alpha and composite reliability. Journal of Applied Psychology, 98 (1): 194-198.

$\mathrm{R}$ Core Team (2017): $R$ : A language and environment for statistical computing. R Foundation for Statistical Computing, Vienna, Austria. URL <https://www.R-project.org/> (2017.10.01.).

Raykov, T. (1997): Estimation of composite reliability for congeneric measures. Applied Psychological Measurement, 21 (2): 173-184.

Rosseel, Y. (2012). lavaan: An R Package for Structural Equation Modeling. Journal of Statistical Software, 48 (2): 1-36. <http://www.jstatsoft.org /v48/i02/> (2017.10.01.).

Rózsa S., Nagybányai N. O., Oláh A. (2006): A pszichológiai mérés alapjai: elmélet, módszer és gyakorlati alkalmazás. Bölcsész Konzocium, MEK, <http://mek.niif.hu/05500/05536/05536.pdf> (2017.10.01.).

Ruekert, R. W. (1992): Developing a Market Orientation: An Organizational Stra-tegy Perspective. International Journal of Research in Marketing, 9 (3): 225-245.

Shapiro, B. (1988): What the Hell is „Market-Oriented”?. Harvard Business Review, 67 (6): 119-125.

\section{Melléklet}

\section{MARKOR \\ Információszerzés}

1 Vállalatunk évente legalább egy alkalommal találkozik vásárlóival, annak érdekében, hogy megtudjuk milyen szolgáltatásokra, vagy termékekre lenne szükségük a jövőben.

2 Vállalatunk egyes alkalmazottai közvetlen kapcsolatban állnak vevőinkkel, annak érdekében, hogy megismerjék miként szolgálhatnánk ki jobban az igényeiket.

3 Vállalkozásunk számos házon beluili piackutatást végez.

4 Képesek vagyunk gyorsan észlelni vásárlóink elvárásaiban bekövetkező változásokat.

5 Évente legalább egy alkalommal végzünk felmérést termékeink végfelhasználóinak körében, hogy felmérjük a termékeinkkel, szolgáltatásainkkal kapcsolatos véleményeket.

6 Gyakran megosztjuk felméréseink eredményeit olyanokkal, akiknek hatásuk van a végfelhasználók vásárlási döntéseire, például kereskedőkkel.

7 Az iparágról szóló információkat informális csatornákon keresztül szerezzük be (pl.: munkaebédeken, vállalati rendezvényeken).

8 Vállalkozásunkban a versenytársakról való információgyưjtést - egymástól függetlenül több vállalati egységnél is fontosnak vélik.

9 Gyorsan képesek vagyunk észlelni az iparágban bekövetkező alapvető változásokat (pl.: technológiai vagy versenykörnyezetben fellépő változás). 
10 Legalább éves gyakorisággal elemezzük az üzleti környezetben bekövetkező változások (pl.: szabályozás) lehetséges hatásait a vásárlóinkra.

\section{Információáramlás}

11 Vállalkozásunkban számos informális beszélgetés vonatkozik a versenytársak stratégiájára, taktikájára.

12 Legalább negyedévente vannak a különböző szervezeti egységek közötti megbeszélések annak érdekében, hogy megvitassuk a piaci trendeket és a szükséges fejlesztéseket.

13 Vállalkozásunkban a marketing területével foglalkozó szakember(ek) fordítanak idöt arra, hogy más funkcionális területekkel (pl.: logisztika, gyártás, könyvelés) megosszák a fogyasztók várható igényeivel kapcsolatos információkat.

14 Vállalkozásunk rendszeresen jelentet meg különbözö dokumentumokat (pl.: jelentések, hírlevelek), amelyek információval szolgálnak vásárlóinknak.

15 Ha valami fontos dolog történik a vállalatunk legjelentősebb vásárlójával, vagy piacával kapcsolatban, akkor arról az egész szervezet rövid időn belül értesül.

16 A vásárlóink elégedettségével kapcsolatos információkat a vállalkozás minden szintjén megfelelően kommunikáljuk.

17 Megfelelő szintủ a.piaci fejlesztésekre vonatkozó kommunikáció a marketinggel foglalkozó szakemberek és a gyártás között.

18 Ha a vállalkozás egyik szervezeti egységének valamilyen fontos információ jut a tudomására a versenytársakról, akkor azonnal értesíti a többi egységet.

$$
\text { Válaszképesség }
$$

19 Nagyon kis időbe telik, míg megtaláljuk a megfelelö választ versenytársaink árainak változására.

20 Vállalkozásunkban a piaci szegmentáció során felmerülő lehetőségek határozzák meg a termékfejlesztési irányokat.

21 Folyamatosan figyelembe vesszük fogyasztóink termékeinkre vonatkozó elvárásainak változását.

22 Meghatározott idöközönként felülvizsgáljuk termékfejlesztési tevékenységünket, annak érdekében, hogy meggyőzödjünk azok fogyasztói igényekkel való egyezőségéröl.

23 Üzleti elképzeléseinket sokkal inkább a technológiai fejlesztési lehetőségek határozzák meg, mint a piackutatás.

24 A vállalat különböző területeinek vezetöi rendszeresen fordítanak idöt arra, hogy közösen kidolgozzák a megfelelő válaszokat az üzleti környezetben bekövetkező változásokra.

25 A vállalkozásban elöállításra kerülő termékvonalakat a valós piaci igények határozzák meg, kevésbé a vállalat belső vélekedése.

26 Ha egy jelentős versenytársunk egy intenzív kampányt indítana megcélozva a mi vevökörünket, akkor a megfelelő válaszlépéseket azonnal képesek lennénk kidolgozni.

27 Vállalkozásunkban a különböző területek vezetöinek tevékenysége megfelelően koordinált, összhangban van.

28 A vevők panaszai sosem találnak süket fülekre vállalkozásunkban.

29 Ha egy nagyszerü marketing tervet sikerül kidolgoznunk, akkor képesek vagyunk azt a megszabott határidők szerint teljesíteni.

30 Képesek vagyunk gyorsan reagálni, ha változás áll be versenytársunk árszerkezetében.

31 Ha észrevesszük, hogy vásárlóink elégedetlenek termékünkkel, akkor képesek vagyunk gyorsan helyesbítö lépéseket tenni.

32 Ha észleljük, hogy vásárlóink szeretnék, ha módosítanánk termékünket, akkor motiváltak vagyunk ennek érdekében jelentős eröfeszítéseket tenni.

\section{MKTOR}

Vevöorientáció

1 Vállalati céljaink kialakítását a fogyasztói elégedettség elérése motiválja.

2. Nyomon követjük a szervezet fogyasztói igények kielégítésének irányába történő elkötelezettségét.

3 A kompetitív előnyöket kihasználó stratégiánk a fogyasztói igények megértésén alapul. 
4 Üzleti stratégiánk mozgatórugója azon meggyőződésünk, hogy hogyan tudunk nagyobb értéket előállítani vásárlóink számára.

5 Gyakran és rendszeresen mérjük a fogyasztói elégedettséget.

$6 \quad$ Nagy figyelmet fordítunk az értékesítés utáni szolgáltatásokra.

7 A vevőinkröl szóló információknak nagy jelentőséget tulajdonítunk a vállalaton belül.

8 Rendszeresen gyüjtjük az információkat a vásárlóinkról.

Versenytárs-orientáció

9 Vállalatunk dolgozói megosztják a vállalaton belül a versenytársak stratégiájára vonatkozó információikat.

10 A versenytársak minket fenyegető lépéseire megfelelően reagálunk.

11 Megfelelően pozícionáljuk magunkat azoknál a fogyasztóknál/fogyasztói csoportoknál, ahol rendelkezünk kompetitív elönyel, vagy képesek vagyunk ilyet kifejleszteni.

12 A versenytársaink tevékenységéröl szóló információknak nagy jelentöséget tulajdonítunk a vállalaton belül.

13 Rendszeresen gyűjtjük az információkat a versenytársainkról.

Funkciók közötti együttmüködés

14 A vállalat különböző funkcionális területeinek első számú vezetői felkeresik a jelenlegi és jövőbeni várható partnereinket.

15 A különböző funkcionális területek között megfelelően kommunikáljuk a fogyasztóinkkal kapcsolatos sikereket és sikertelenségeket is.

16 Minden funkcionális területünk (pl.: marketing, értékesítés, $\mathrm{K}+\mathrm{F}$, könyvelés) müködése a fogyasztói igények lehetö leghatékonyabb kielégítésének van alárendelve.

17 A vállalat vezetöinek mindegyike tisztában van azzal, hogy ki hogyan tud hozzájárulni a termék fogyasztói értékének létrehozásához. 